\title{
Land Use Change at Sub-Watershed Level
}

\section{Sristika Adhikari ${ }^{1 *}$, Suman Man Shrestha ${ }^{1}$, Reeta Singh ${ }^{2}$, Suraj Upadhaya ${ }^{3}$ and Jared R Stapp ${ }^{4}$}

${ }^{1}$ Environmental Science Program, Institute of Science and Technology, Central Department of Environment Science, Tribhuvan University, Kirtipur 44618, Kathmandu, Nepal

${ }^{2}$ Environmental Science Program, Department of Environmental Science, Patan Multiple Campus, Patan, Nepal

${ }^{3}$ Integrative Conservation of Nature and Forestry, Warnell School of Forestry and Natural Resources, University of Georgia, 180 E Green Street, Athens, GA 30602, United States of America

${ }^{4}$ Environmental Science, Policy and Management Program, University of California, Berkeley, 326 Mulford Hall, Berkeley, CA 94720, United States of America

\begin{abstract}
Land Use and Land Cover Change (LULCC) is a major driver of environmental problems like water pollution, decreased soil quality, and natural resource scarcity. Measuring LULCC is necessary to better understand the present condition of watersheds. Time series LULCC mapping using Geographic Information Systems (GIS), high-resolution imagery, and field data collection are effective methods for examining LULCC trends. The Mahadev Khola watershed in Bhaktapur, Nepal, acts as a primary source of drinking water for people living within the Bhaktapur municipalitywhich is dominated by forest at higher elevations and agricultural lands and settlements at lower elevations. The purpose of this study was to observe LULCC dynamics within the Mahadev Khola watershed to better understand the social and environmental problems that can arise in consequence. Time series land use maps were created and analyzed using GIS methods. Responses from a survey of local people, as well as interviews from selected key stakeholders, contribute insight into how past scenarios of land use have influenced-and have been influenced by-LULCC. Significant changes in land use were quantified between 2005 and 2014 . Results suggest that in this period, total forest area decreased by $6.25 \%$, cultivation area decreased by $14.28 \%$ and settlements increased by $156.25 \%$. Survey and interview responses suggest that much of this change is due to agricultural intensification and an increase in chemical fertilizer and pesticide use. Increased agricultural inputs have increased the potential for river and water pollution and long term soil degradation. Urban expansion and development have led to the contamination of rivers with sewage and solid waste, which has increased health risks for local communities. Although total forest area has increased, the species composition has changed-now primarily dominated by Pinus roxburghii. The result of this is a decrease in river water discharge and increase in soil and water acidity. The results of this study are timely and important for analyzing the dynamics between LULCC and watersheds in order to improve future management efforts in Nepal and the Eastern Himalayan region of South Asia.
\end{abstract}

Keywords: Agricultural runoff; GIS; Forest conservation; LULCC; Pollution; Soil quality; Mahadev Khola Watershed

\section{Introduction}

A watershed is a topographically delineated area that drains rain, snowmelt and ground water into a stream or river-system (Corn et al. $[1,2])$. Human activities like agriculture, solid waste disposal and land use patterns like forest area, croplands, settlement area have transformed the geographical environment (Turner et al. [3]), and today, many environmental problems such as water pollution is linked with land use and land cover change (LULCC). LULCC challenges have been at the international forefront of integrated environmental research in recent years (Cai [4]), and this study contributes to the literature by examining the complex relationships that exist between communities and their natural environments in Nepal-a country that increasingly faces natural resource sustainability issues and human health and subsistence challenges. Land use and human activities within a watershed can lead to drainage and runoff of anthropogenic substances into water bodies. Studies have shown that watershed quality is greatly affected by human activities through point sources such as wastewater treatment facilities, and non-point sources such as urban and farm land runoff (Sharma et al. [5]).

Estimating historical LULCC trends is essential in assessing the rate at which change occurs and the problems that result, which can lead to better predictions of future impacts and issues that might occur (Lambin [6]). LULCC degrades important ecosystem services of watersheds such as soil and water quality, biodiversity, microclimates, methane emissions, and $\mathrm{CO}_{2}$ sequestration, (Lambin et al. $[7,8]$ ). An increased understanding of these impacts improves the estimation, forecasting, and modeling of watershed system dynamics at local, regional, and global scales (Chen et al. [9]). Heggem et al. [10] used a landscape ecology approach in a Louisiana watershed of USA to reveal its increasingly distressed condition over a 20 year period, and causes for this distressed condition were decrease in forest coverage, construction of new roads, stream crossings, etc.

Due to watershed degradation caused by LULCC, impacts like decline in river water quality are seen in Nepal. Throughout recent decades, degraded watersheds have posed serious problems for the environment and people living within, both upstream and downstream (Mountain [11]). Communities have increasingly acknowledged that land degradation is a serious threat to the environment and to the wellbeing of a large proportion of people living in developing countries (Ives et al. [12-15]). The Middle Hills and northern mountains of Nepal

*Corresponding author: Sristika Adhikari, Environmental Science Program, Institute of Science and Technology, Central Department of Environment Science Tribhuvan University, Kirtipur, Kathmandu, Nepal, Tel: +91977015091147; E-mail: sristiadhikari7@gmail.com

Received August 03, 2016; Accepted August 23, 2016; Published August 30 2016

Citation: Adhikari S, Shrestha SM, Singh R, Upadhaya S, Stapp JR (2016) Land Use Change at Sub-Watershed Level. Hydrol Current Res 7: 256. doi: 10.4172/2157-7587.1000256

Copyright: ( $) 2016$ Adhikari S, et al. This is an open-access article distributed under the terms of the Creative Commons Attribution License, which permits unrestricted use, distribution, and reproduction in any medium, provided the original author and source are credited. 
are fragile ecosystems with poor agricultural potentiality, partially due to the steep slopes and fragile geology. Studies conducted in Nepal have shown that forest depletion, land degradation, improper water management, and food security are problems created by unsustainable and negligent watershed management (Blaikie et al. [1619]). In cultivated areas of Nepal with sufficient irrigation, agricultural intensification has led to an increase in crop yields between $200 \%$ and $300 \%$ (Brown et al. [20]), which has increased soil erosion over time (Tiwari et al. [21]). The trending drop in agricultural productivity in Nepal is perhaps a result of increasingly poor soil quality; however, the literature lacks sufficient studies in this field. Therefore this study is important to find out possible threads to river water quality from land use change.

Effective management of forest and other natural resources within a watershed requires an understanding of resource changes over time and space alongside human activities (Naiman et al. [22]). In an investigation on the state of all watersheds in the Middle Hills of Nepal in $1980,3 \%$ and $16 \%$ of watersheds were classified as being in poor and fair condition, respectively; whereas $18 \%$ and $63 \%$ were found to be in good and excellent condition, respectively (Nelson et al. [23]). Although these results suggest that the majority of watersheds in the Middle Hills were in either good or excellent condition, today, they are on the verge of degradation (Shrestha et al. [24]). Both the Kathmandu and Bhaktapur districts of Nepal are classified as impoverished [24]. Nina [25] notes that watershed degradation concerns water resources rather than land productivity; however, the two are closely related because loss of nutrients and soil particles often results in decline in the quality of water entering the water ways.

Of the many supported methods for collecting data about watershed health, mapping and analyzing LULCC using GIS and RS are commonly utilized, powerful tools (Tekle et al. [26]), and play an important role in solving various natural resource management challenges relating to LULCC (ESCAP [27]). The watersheds in the Bhaktapur district of Nepal are being degraded because of LULCC. River water quality is decreasing while the population and demand for water is increasing. Very little watershed research has been done in Bhaktapur. Here, we detect and document LULCC and the associated environmental and social impacts in the Mahadev Khola watershed by using RS and GIS techniques, supplemented by survey data collection.

\section{Study Area}

The Mahadev Khola watershed is located in the Bhaktapur district, which lies in the Central region of Nepal, $20 \mathrm{~km}$ east of Kathmandu. It lies within in the Boundary of Nagarkot Municipality (Figure 1). The total area of the Mahadev Khola watershed taken for the study is 7.42 $\mathrm{km}^{2}\left(27.69^{\circ} \mathrm{N}\right.$ to $\left.85.51^{\circ} \mathrm{E}\right)$, with elevation ranging between $1320 \mathrm{~m}$ and $2135 \mathrm{~m}$. The name 'Mahadev Khola' is given because the primary river here originates from Mahadev Pokhari of Nagarkot Municipality. It flows between Nagarkot and Bageswori Hill to join the Hanumante River, which then unites with the Bagmati River in Imadol, Lalitpur. Our study area is classified as subtropical with a mild climate and monsoon season between June and September. The average annual precipitation is $1400 \mathrm{~mm}$. The general climatic condition is cold in winter and hot in summer with average temperatures ranging from $2^{\circ} \mathrm{C}$ in the winter and $35^{\circ} \mathrm{C}$ in the summer.

\section{Methodology}

\section{For land use map}

Land use maps were created for the years 2005 and 2014 from Google earth images using GIS and RS. Techniques used were watershed delineation, DEM (Digital Elevation Model) preparation, delineating land-cover, giving symbol to land cover, projecting the prepared land cover map and calculating area through spatial analysis. Before the interpretation of land use map, survey was carried out in study area during May 2014. During survey, field observation was done to find out actual land use pattern in the watershed. Field visit was done to study about forest composition. Land cover was created for two different periods by manually digitizing land cover types over High-Resolution (HR) Google Earth images from Digital Globe and digital topographical maps (Figure 2).

\section{Field verification}

Field verification of land cover map was carried out in July 2014 for confirming that land cover map created lies within corresponding natural boundary. After field verification, some corrections were made in land use map before finalizing.

\section{Data collection}

Additionally, survey data from local people and key informants living in the Mahadev Khola watershed were collected to better understand and interpret the LULCC scenarios that emerged from the RS and GIS analysis. Survey was conducted by purposive sampling method. Total house hold number in study area is 197 and total sample size calculated was 62 . All 62 people responded to the survey questions. Key informants like official members of Municipality and District Forest Office along with elderly people of the study site who has day to

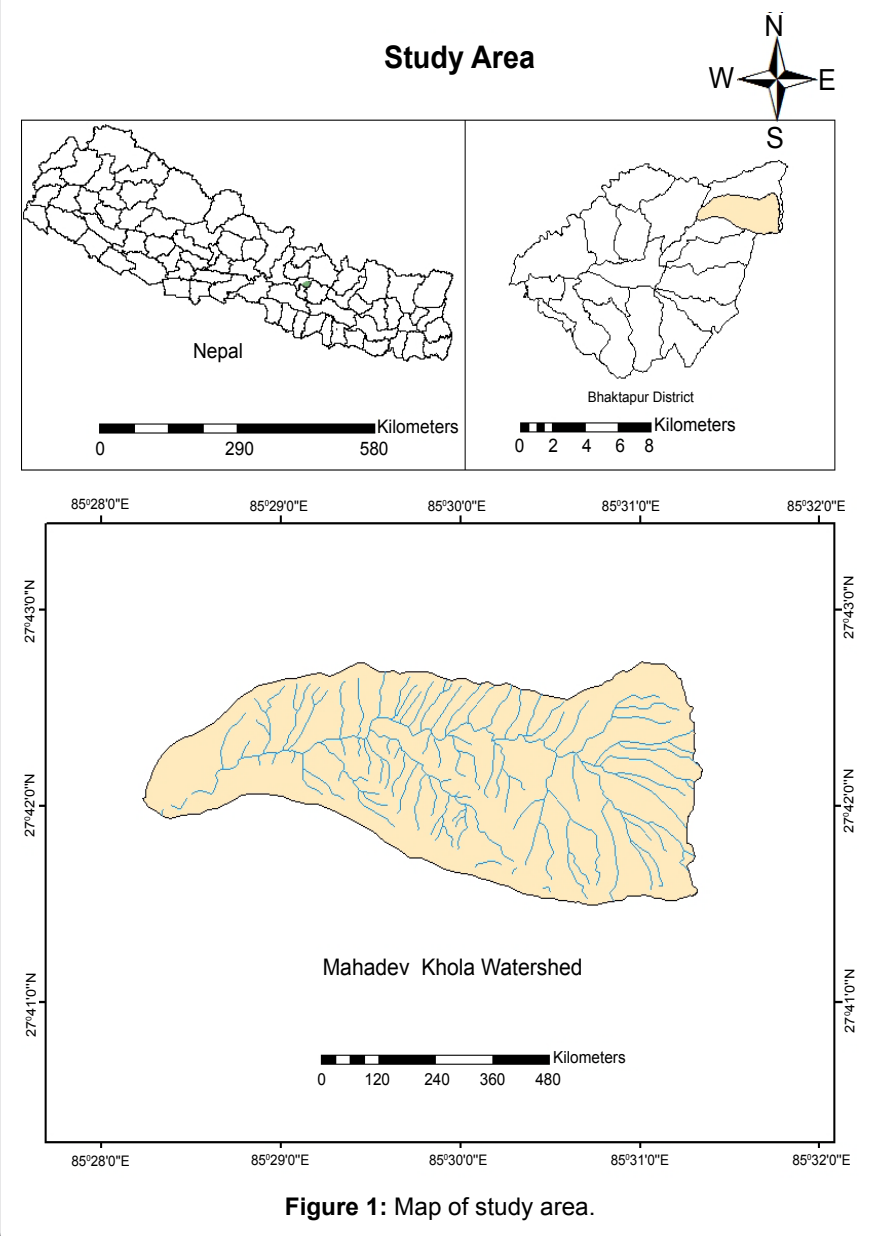


day experience of land use change of Mahadev Khola Watershed were interviewed. Format of semi structured schedule survey is provided below in annex. Purpose of conducting this survey is to understand the people's perception about land use change and its impact in river water quality. Sample size was calculated from formula given by Arkin and Kolton.

$$
n=\frac{N\left\{d^{2}+Z^{2} \times P(1-P) I\right\}}{N Z^{2} \times P(1-P)}
$$

Where,

$$
\mathrm{n}=\text { sample size }
$$

$\mathrm{N}=$ total no. of household

$\mathrm{Z}=$ abscission of normal curve i.e., confidence level (at 95\%, $\mathrm{Z}=1.96$ )

$\mathrm{P}=$ estimated population proportion $(0.05)$

$\mathrm{d}=$ margin of error limit ( \pm 5 i.e., 0.05 ).

A digital elevation model (DEM) was prepared from a contour map of the Kathmandu valley, followed by the delineation of the Mahadev Khola watershed. The boundary shape file of the watershed was overlaid onto HR Google Earth images and land coverage of settlement, forest and cultivation land was digitized for the years 2005 and 2014, the maps were transferred to ArcGIS 9.1 software, and land cover was symbolized and categorized for each year. Area and change statistics were calculated and analyzed for three classes-forest, cultivated land, and settlements-between the two dates. Area was calculated by spatial analysis tool and significant difference in areas was calculated by Spearman's correlation test by SPSS 16.0 software.

\section{Results}

A significant difference was found in Land cover between 2005 and 2014 with $\mathrm{P}$ values 0.5 . Changes in forest cover, cultivated land, and settlements can be seen in Figure 3.

\section{Forest cover}

The total area of forest cover decreased from $6.40 \mathrm{~km}^{2}$ in 2005 to $6 \mathrm{~km}^{2}$ in 2014-a loss of 6.25\% (Figure 3). Responses from our field survey with local people suggest that forest cover had decreased due to increase in settlement in upstream region of the watershed.

\section{Cultivated land}

The total area of cultivated land fell from $0.70 \mathrm{~km}^{2}$ in 2005 to $0.60 \mathrm{~km}^{2}$ in 2014 - an overall decrease of $14.28 \%$ (Figure 3). This decrease in cultivated area in 2014 due to an increase in settlementsboth upstream and downstream in the Mahadev Khola watershed. Direct field observations in cultivation land and interviews with local farmers show that although cultivated land area has decreased, the use of intensive agricultural practices has increased. Hundred percent of the respondent has agreed that agriculture has been intensified and cash crops farming has increased. Field observations made by walking along the river bank from origin to the confluence revealed a common practice of disposing agricultural residue and runoff into the river. In the Mahadev Khola watershed, vegetables are a commonly grown as cash crops, and synthetic pesticides and fertilizers is used in excessive amounts to increase yields (Table 1).

\section{Settlements}

Perhaps the most remarkable changes seen in this analysis were for settlement areas. Settlements have increased rapidly in the watershed. In 2005, the total area of settlements in the Mahadev Khola watershed was only $0.32 \mathrm{~km}^{2}$, which increased to $0.82 \mathrm{~km}^{2}$ in 2014 -expanding $156.25 \%$ (Figure 3). Responses from local people suggest that settlements have primarily expanded along roadsides.

\section{Discussion}

According to local people, VDC officers, and the District Forest Office, the high amount of forest cover seen in 2005 was the result of decentralization policies that converted state-managed forests into community forests. Additionally, many trees were grown and replanted in 1985. Local people, VDC officers, and the District Forest Office attributed the loss of forest cover between 2005 and 2014 to the removal of trees to build hotels and restaurants for tourist-driven economic development. Through observations made by walking along the forest area it was also found that forest cover has been greatly fragmented by the construction of new roadways.

Main tree species in forests within our study area was Pinus roxburgii, it was known through walking and observing in forest. Native species-such as Schima wallichi, Vitex negudo, Castronopsis

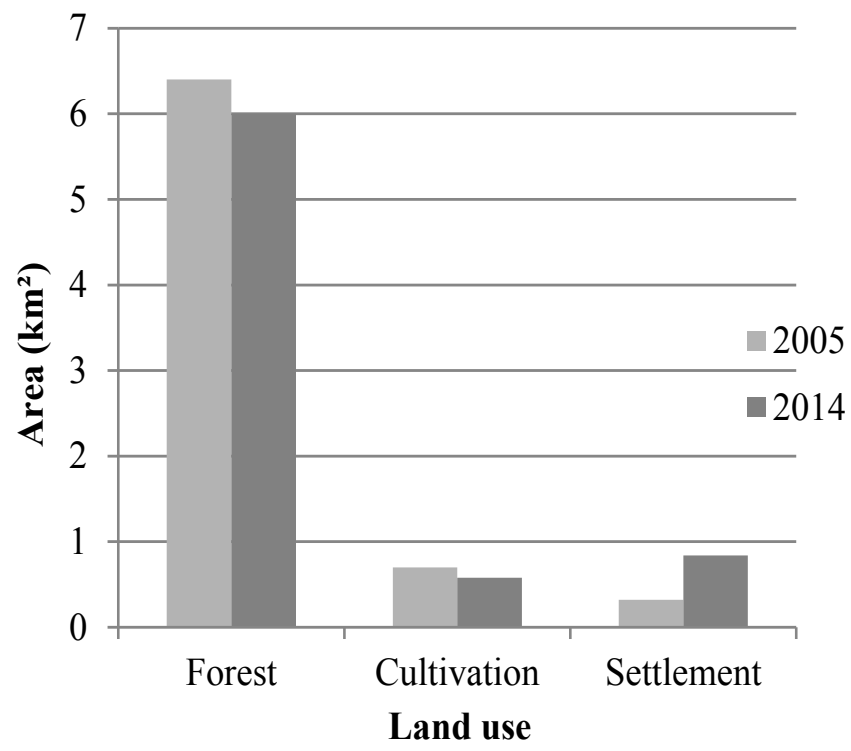

Figure 2: Land use in 2005 and 2014.

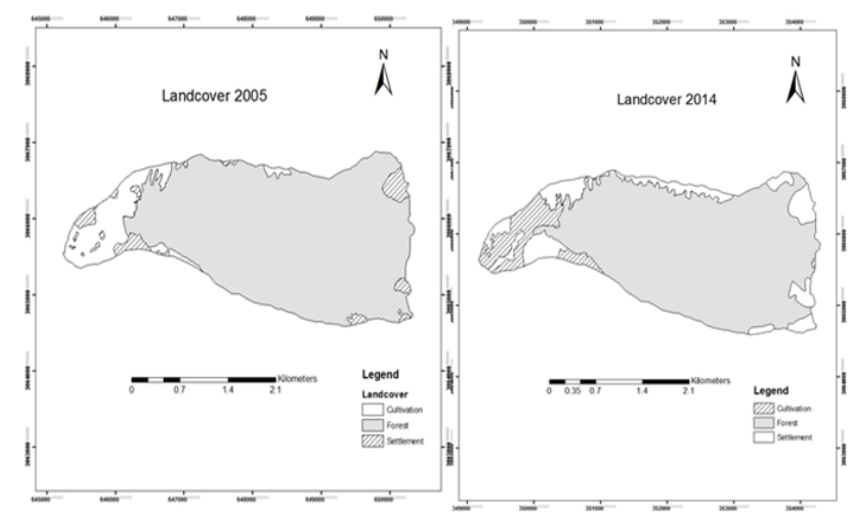

Figure 3: Land cover map of 2005 (left) and 2014 (right). 


\begin{tabular}{|c|c|c|c|c|}
\hline Land use type & $\begin{array}{c}\mathbf{2 0 0 5} \text { area } \\
\mathbf{( k m}^{\mathbf{2}} \mathbf{n}\end{array}$ & $\begin{array}{c}\mathbf{2 0 1 4} \text { area } \\
\mathbf{( k m}^{\mathbf{2}} \mathbf{m}\end{array}$ & $\begin{array}{c}\text { Change in } \\
\text { area } \mathbf{( k m}^{\mathbf{2}} \mathbf{)}\end{array}$ & $\begin{array}{c}\text { Change in } \\
\text { area (\%) }\end{array}$ \\
\hline Forest & 6.40 & 6.00 & -0.40 & -6.25 \\
\hline Cultivation & 0.70 & 0.60 & -0.10 & -14.28 \\
\hline Settlements & 0.32 & 0.82 & 0.50 & 156.25 \\
\hline Total & 7.42 & 7.42 & & \\
\hline
\end{tabular}

Table 1: Area and percentage of land use change.

indica, Barsia latifolia, and Prunus cerasodis were present in less number. These local species were more water storing than Pinus sp. It was found that in four micro-catchments in the Paute river basin in south Ecuador, reforestation efforts that utilized pine species (i.e., Pinus patula) led to a decrease in water yields when compared to the standardized practice of intensive grazing and potato cultivation. In their study, two watershed catchments were covered with natural grassland vegetation, one was converted to pine forest, and one was partially grazed and partly cultivated with potatoes. Results indicated that afforestation with $P$. patula reduced the water yield by about $50 \%$ or an average of $242 \mathrm{~mm}$ annually. A study conducted by Prajapati [28] concluded a similar result; pine trees (i.e., Pinus roxburghii), planted on the hill slopes of Nagarkot forest in Nepal, were found to decrease the water holding capacity of the watershed catchment. Native trees species were found to be superior to Pine tree species in retaining soil moisture and purification processes [28].

This analysis also shows a remarkable increase in settlements, located within the watershed. New houses are increasingly being built as the population increases. The population of the upstream portion of the Mahadev Khola watershed increased from 8,390 in 2001 to 11,212 in 2011 (GoN, 2001 and GoN, 2011)-a trend that is rapidly increasing. Our results suggest that total settlement area increased by $156.25 \%$ between 2005 and 2014, which coincides with rapid population increase data and the increase of hotels and lodges for tourism-related economic expansion. Field observations made by walking along the river reaches, interview with local people showed that these rapid changes in land use have negatively impacted water quality-primarily caused by sewage disposal and solid waste dumping from newly-established settlements. We witnessed direct sewage discharge from houses and solid waste dumping in river banks mainly in the downstream settlement areas. Halstead et al. [29] concluded that anthropogenic sources of pollution such as synthetic fertilizers and discharge from septic systems and sewers significantly contributed to 'urban stream syndrome' Common effects of urbanization on stream ecosystems have been referred to as the "urban stream syndrome" (Walsh et al. [30]), and there is a strong association between water quality and increased settlement area.

Interviews with local farmers additionally revealed that, although cultivated lands have decreased in area, farmers are shifting from traditional agricultural methods to modern methods of intensification. Survey responses suggest that the use of chemical fertilizers and pesticides has increased several folds in recent years. Hundred percent of the respondent said that they are using chemical fertilizer, pesticides and insecticides for growing crops. In areas of Nepal with available irrigation water, intensification has led to a $200-300 \%$ gain in crop yields [20], however, these practices have been found to increase soil erosion long-term [21]. Although few studies have examined the reasons for sharp reductions in agricultural productivity in this region, some suggest that it is primarily a result of increasingly poor soil quality [25]. The results from our study show that intensification in agriculture by farming inside the green house structures made by plastic tents has increased rapidly in recent years. Farmers now typically grow cash crops such as tomatoes, cucumber, beans, cauliflowers and cabbage inside green houses, and this shift in cultivation practices by intensified use of insecticides and pesticides has greatly increased river water pollution from agricultural runoff and residue disposal. There are higher levels of nutrients and organic concentrations in runoff from watersheds with more agricultural activities (Kim et al. [31]). Over long time spans, stream channels, agricultural fields, and other disturbed areas become unstable and exhibit wide fluctuations in the rate of soil erosion due to the formation of new drainage systems [32].

\section{Conclusion}

This study shows that interpreting LULCC maps that represent a time period between 2005 to 2014 can help in bettering our understanding of land use change patterns in Nepal. GIS tools like DEM preparation, watershed delineation, land cover preparation etc. are useful for quantifying and interpreting change results. Our results suggest that there between 2005 and 2014, there were significant changes in forest cover, settlement area, and cultivated area in the Mahadev Khola watershed. Forest and cultivation area has been decreased while settlement area has been increased. Results for survey in cultivation area and interview with local farmers also show an increase in agricultural intensification within the watershed. These changes in land use and land cover can have negative impacts on the soil and river water quality within the watershed. There are many factors associated with the expansion of settlements that threaten the future of this study site, particularly increased sewage disposal and solid waste dumping in rivers. Intensified agricultural practice threatens soil quality and river water quality due to the application of excessive amounts of chemical fertilizers and pesticides, which inevitably runoff into the river. This trend is likely to continue in future. The forest here has experienced changes in species composition with the replacement of local broad leaved tree species by Pinus roxburghii. This will likely increase the acidity of the soil and decrease the rate of water discharge into the rivers. There is not any action plan underway to resolve this issue. Plantation program has not been held since 1985. So, the problem of increase in acidity and decrease in water discharge onto the river may increase in future. It is necessary to plant native species of broad leaved tree species to replace the Pinus roxburghii. The Mahadev Khola watershed is the main source of drinking water for people living within the watershed. Scarcity of drinking water is caused by an increase in demand and decrease in river discharge. For these important reasons, this study provides invaluable data to better our understanding of the effects of past land use trends so that we can empirically predict the future environmental effects of human behavior in the Mahadev Khola watershed and elsewhere in Nepal and the Eastern Himalaya region of South Asia.

\section{Acknowledgements}

We thank the local community people of the Mahadev Khola watershed for cardinal co-operation throughout the research period. Beside this we would like to thank officials of Nagarkot Municipaity and District Forest Office, Bhaktapur.

\section{References}

1. Corn ML (1993) Ecosystems, Biomass, and Watersheds: Definitions and Use Washington, DC. National Council for Science and the Environment.

2. Swallow MB, Johnson NL, Meinzen-Dick RS (2001) Working with People for Watershed Management. Water Policy 3: 449-455.

3. Turner BL, Clark WC, Kates RW (1990) The Earth as Transformed by Human Action: Global and Regional Changes in Biosphere over past 300 Years. Cambridge: Cambrige University Press. 
Citation: Adhikari S, Shrestha SM, Singh R, Upadhaya S, Stapp JR (2016) Land Use Change at Sub-Watershed Level. Hydrol Current Res 7: 256. doi: 10.4172/2157-7587.1000256

4. Cai $Y$ (2001) Study on landuse/landcover changes: searching for new approaches to integration. Geographical Search 20: 645-652.

5. Sharma S, Allen M, Caurage A, Hall H, Koirala S, et al. (2005) Assessing Water Quality for Ecosystem Health of Babai River in Bardia National park. Kathmandu University Journal Of Science, Engineering And Technology 1: 1-13.

6. Lambin EF (1997) Modeling and monitoring land-cover change processes in tropical region. Progress in Physical Geography 21: 375-393.

7. Lambin EF, Rounsevell M, Geist H (2000) Are current agriculture land use models able to predict changes in land-use intensity? Agriculture, Ecosystem and Environment 82: 321-331.

8. Schneider LC, Pontius RG (2001) Modeling land-use change in the Ipswich watershed, Massachusetts, USA. Agriculture, Ecosystems and Environment 85: 83-94.

9. Chen L, Wang J, Fu B, Qu Y (2001) Land-use change in small catchment of northern Loess plateau, China. Agriculture, Ecosystems and Environment 86: 63-172.

10. Heggem DT, Edmonds MC, Neale AC, Bice L, Jones KB (2000) A landscape ecology assessment of the Tensas River Basin. Environment Monitoring Assesment 64: 41-54.

11. Mountain (2002) Watershed Management. Beyond the International Year of Mountains. Retrieved December 12, 2004 from: http://www.mountainpartnership.org/themes/i-watershed.html

12. Ives JD, Messerli B (1989) The Himalayan Dilemma: Reconciling Development and Conservation. UNU The United Nations University, Routledge London and New York.

13. Oldeman LR (1994) The Global Extent of Soil Degradation. In: Greenland DJ and Szabolces I (eds.), Soil Resiliencies and Sustainable Land Use, Walling, UK: CAB International, 99-118.

14. Jodha NS (1995) The Nepal Middle Mountains. In: Kasperson J, Kasperson RE and Turner BL (eds.), Regions at risk: comparisons of threatened environments. Tokyo: United Nations University Press, pp: 140-185.

15. Lal R (1998) Soil Erosion Impact on Agronomic Productivity and Environment Quality. Critical Reviews in Plant Science 17: 319-464.

16. Blaikie P (1987) Explanation and Policy in Land Degradation and Rehabilitation for Developing Countries. Land Degradation and Rehabilitation 1: 23-27.

17. Carson B (1992) The land, The farmer, and The future: A Soil Fertility Management Strategy for Nepal. ICIMOD Occasional Paper No 21, Kathmandu, Nepal.

18. Thapa GB, Weber KE (1993) Managing Mountain Watersheds: the Upper Pokhara Valley. Bangkok: Asian Institute of Technology, Division of Human Settlements Development.
19. Pandit BH, Thapa GB (2004) Poverty and Resource Degradation Under Different Common Forest Resource Management Systems in the Mountains of Nepal. Society and Natural Resources 17: 1-16.

20. Brown S, Schreier H, Shah PB, Lavkulich LM (1999) Modelling of soil nutrient budgets: an assessment of agricultural sustainability in Nepal. Soil Use and Management 15: 101-108.

21. Tiwari KR, Sitaula BK, Bajracharya RM, Børresen T (2009) Runoff and soi loss responses to rainfall, land use, terracing and management practices in the Middle Mountains of Nepal. Acta Agriculturae Scandinavica, Section B-Soil and Plant Science 59: 197-207.

22. Naiman RJ, Bisson PA, Turner MG (1997) Approaches to management at the watershed scale. In: Kohm KA, Franklin JF (eds.), Creating a Forestry for the 21st Century: The Science of Ecosystem Management, Island Press.

23. Nelson DO, Laban P, Shrestha BD, Kandel GP (1980)A reconnaissance inventory of the major ecological land units and their watershed condition in Nepal.

24. Shrestha BD, Van Ginneken P, Sthapit KM (1983) Watershed condition of the districts of Nepal.

25. Nina W (2013) Investigation of Water Quality in Forested and Agricultura Watershed. Master Thesis, Norwegian University of Life sciences, Department of Plant and Environmental Sciences.

26. Tekle K, Hedlund L (2000) Land cover changes between 1958 and 1986 in Kalu District, Southern Wello, Ethiopia. Mountain Resource Development 20: 42-51.

27. ESCAP (Economic and Social Commission for Asia and the Pacific) (1997) Guidelines and Manual on Land-use Planning and Practices in Watershed Management and Disaster Reduction. ESCAP, United Nations.

28. Prajapati M (2012) Scope of Payment for Ecosystem Services Mechanism for better water and watershed management in Bhaktapur. MSc Thesis, Khwopa College, Tribhuvan University.

29. Halstead JA, Kliman S, Catherine WB, Chaucer A, Cock A (2014) Urban stream syndrome in a small, lightly developed watershed: a statistical analysis of water chemistry parameters, land use patterns, and natural sources. Environment Monitoring Assessment 186: 3391-3414.

30. Walsh CJ, Fletcher TD, Ladson AR (2005) Stream restoration in urban catchments through redesigning stormwater systems: looking to the catchment to save the stream. Journal of the North American Benthological Society 24 : 690-705.

31. Kim G, Chung S, Lee C (2007) Water quality of runoff from agriculturalforestry watersheds in the Geum River Basin, Korea. Environment Monitoring Assessment 134: 441-452.

32. Osterkamp WR, Toy TJ (1997) Geomorphic considerations for erosion predictions. Environmental Geology 29: 152-157. 